\title{
Contribution of Islamic Social Capital on Green Economic Growth in Malaysia
}

\author{
Nazrah Abdul Hamid \\ Arshad Ayub Graduate Business School \\ Universiti Teknologi MARA \\ 40450 Shah Alam, Selangor, Malaysia \\ Email: nazrah.abdulhamid@yahoo.com
}

Ruhaini Muda*

Faculty of Business and Management

Universiti Teknologi MARA

40450 Shah Alam, Selangor, Malaysia

Email: ruhaini@salam.uitm.edu.my

Md. Mahmudul Alam

School of Economics, Finance \& Banking

Universiti Utara Malaysia

06010 Sintok, Kedah, Malaysia

Email: rony000@gmail.com

\section{Normah Omar}

Accounting Research Institute

Universiti Teknologi MARA

40450 Shah Alam, Selangor, Malaysia

Email: normah645@salam.uitm.edu.my

Farah Aida Ahmad Nadzri

Accounting Research Institute

Universiti Teknologi MARA

40450 Shah Alam, Selangor, Malaysia

Email: aidanadzri@uitm.edu.my

*Corresponding author

\section{Citation Reference:}

Hamid, N.A., Muda, R., Alam, M.M., Omar, N. \& Nadzri, F.A.A. (2019). Contribution of Islamic Social Capital on Green Economic Growth in Malaysia. International Journal of Business and Management Science, 9(2): 239-256. (online) http://www.safaworld.org/ijbms/v9n2.htm

This is a pre-publication copy.

The published article is copyrighted by the publisher of the journal. 


\title{
Contribution of Islamic Social Capital on Green Economic Growth in Malaysia
}

\begin{abstract}
This paper studies the relationship between social capital on the green growth in Malaysia, with the aim of ascertaining whether faith based social capital has a role in sustaining economic growth. The study utilizes the annual data over the period of 1970-2015. This study employs the Autoregressive Distributed Lag (ARDL) model and causality using the Vector Error Correction Model (VECM). The findings demonstrate the long and short-run associations between social capital and green growth in Malaysia. The causality only runs in a unidirection from social capital to the green economic growth. The findings have important policy implications for green economic growth measurement to account for social well-being and to fulfil the objectives of Islamic Sharia.
\end{abstract}

Keywords: Green Economy; Social Capital; Consumption; Zakat; Maqasid al-Shariah; Malaysia

\section{Introduction}

The current economic growth refers to the real growth in Gross Domestic Product (GDP), which is computed as a sum of all final goods and services produced within a period of time at market prices. In addition, it is measured by adding a nation's personal consumption expenditure, government spending, net exports, and net capital formation. It is noted that from the sustainability perspective, the computation of GDP ignores externalities, which only measures what is produced and discounts what is needed to generate the production. Hence, based on the computation of the GDP, it does not measure the sustainability of economic growth that ignores a measurement of social welfare (Zheng \& Chen, 2007; Constanza et al., 2009; Vaghefi et al., 2015). It focuses on all sectorial activity as the prime solution rather than the traditional GDP in order to have a more accurate measurement of the economic growth in a country.

It is crucial to facilitate the needs and manage the changes of manpower, physical resources, industrial practices, economic development and humanity, towards rampant environmental crisis around the globe. Recently, the green economic growth has been recognised as a tool in achieving social capital equilibrium and sustainability. Currently, the green economic growth is applicable to human beings and nature, embracing the entire economy (Nasr, 1992; Chishti, 2003). In addition, the green economic indicator will contribute a positive impact to nature, provide a new opportunity in terms of business direction, and create a new skill-set of labour in the market. This is to ensure that we would be able to preserve the environment through sustainable development and an eco-friendly world. Likewise, the green economy concept is recognised as being more productive with efficient solutions to the entire economic eco-systems. The transformation of the economic approach into the green economic growth might be difficult in a short period of time but the success would depend a lot on the strategic planning and the positive acceptance level of the society during the preliminary execution by the government.

The United Nation Environment Programme (UNEP, various issues) has mentioned that the green economy concept is one of the decisions to improve human well-being and social equity, in order to minimize environmental threats and ecological inadequacies drastically. It should be maintained and improvised by any necessary ways, in order to reconstruct the natural capital as a perilous economic asset and a source of public benefit, 
especially for poor societies whose incomes and security depend solely on natural resources. The recent 2015 Paris Climate Conference, the 21st. Conference of the Parties (or "COP21") organized by the United Nations proposed the Paris Agreement, so called a "global consensus", to curb with climate change, with the representation of 196 participating parties around the world. The advancement of dignity, justice, prosperity, people, planet, and partnership for all humanity could be negatively impacted by the imbalance of economic activity conducted by humans themselves.

Malaysia is an emerging economy and a Muslim country that has targeted to achieve vision 2020 to become a developed nation. In Malaysia, the green economy concept has been initiated by the government in terms of evolution in technology, through the establishment of the Ministry of Energy, Green Technology and Water (KeTTHa) in year 2009. Under Eleventh Malaysia Plan (RMK, 2015), the government had introduced the Malaysian Quality of Life Index (MQLI) in 1999 to provide an aggregate measure of sustainable living (EPU, 1999). It emphasizes the importance of a balanced development, which is able to support a sustainable economic growth, hence providing a high quality of life to the society (EPU, 2011 $\&$ 2013). The pro-active measure of the Malaysian government in MQLI (2011) and the green economy concept appears to complement each other in fulfilling the needs of the entire society.

As reported by the OECD Investment Policy Review in 2013, the Malaysian government has placed a positive emphasis on implementing sustainable development, and has understood the need to preserve the environment rather than solely focusing on the economic development of the country. A vast change in terms of environmental policy and public acceptance of the environmental effect on their living quality is essential. Therefore, a complete policy and legislation have been drafted which is inclusive of the climate change National Policy, a Green Technology policy and a Renewable Energy policy for Malaysia (KeTTha, 2015). All this pro-active actions have been created to show the viable movement of the government to support green growth for the benefit of the society. According to Hezri and Ghazali (2011) Malaysia's national green economy framework reflects a mainstream economics framing, such as that of the United Nation Economics Programme (UNEP) and the Organization for Economics Co-operations and Development (OECD). The main intention is to strengthen the Malaysian economy through incentives, tax systems, pricing, regulatory frameworks, and prioritizing all investments (LESTARI, 1999). The measurement focuses more on urban industries and not on rural areas whereby poverty issues and income distributions are still become huge challenges to the country.

However, currently Malaysia has encountered environmental issues after experiencing abundant economic growth (GDP) with the increase in pollution (i.e. increase of $\mathrm{CO}_{2}$ emissions), marine and water pollution (i.e. decrease in terms of overfishing activity and coral reef destructions), deforestation, soil and coastal erosion. For instance, the deforestation is due to the higher demand of palm oil production by the global market (Max, 1995; Lubchenco, 1998; Holling, 2000; Jan, 2015). These issues will continuously occur if human beings and their economic activities do not intensively balance their needs and demand in their wealth accumulation or income generation. Therefore, there is a need to find out the important factors for the solution the problem.

Based on the socioeconomic profile of the people in Malaysia, a majority of the population is Muslim and follows the Islamic rules and regulations known as Shariah. The objectives of Shariah (Maqasid al-Shariah) are inclusive of (absolute) all human acts related to 'ibadah' or 'muamalah' (Akram, 2013; Al-Jayyousi, 2008; 2012). The five (5) main factors that represent the Dharuriyyah (Essential) element under Maqasid al-Shariah are the protection of life, intellect, faith, lineage, and property, which could be fulfilled by espousing 
the green economic concept in our conduct (Alam et al., 2015). In this perspective, obviously the green economy encompasses both "Fiqhul-Ibadah" and "Fiqhul-Muamalah" for the preservation of a harmonious society and for ensuring an efficiently conducted economic development for the benefit of the current life and for future generations. Moreover, this noble conduct could be verified in a few Islamic legal maxims such as "acts are judged by intentions", "harm must be eliminated", and "harm is removed as far as possible" (Auda, 2008). Islam encourages the average approach in all conduct but the nature of human beings that it is embedded with negative values such as selfishness and greed. There are various evidences that associate the imbalance of economic development in a country that causes harm to the society and other living creatures. For example, the acquisition and management of wealth/income in Islam is in accordance with the objectives of life as indicated in the Maqasid al-Shariah in which Muslims are advised to be successful in this world and the hereafter.

Islam considers a human being as vicegerent or Khalifah who has a significant role in leading and preserving the earth. Abdalati (1980) describes the word Khalifah in a wider interpretation. The real owner of wealth is Allah (SWT). Therefore, the owners of wealth are considered trustees (Amanah) and are not unreservedly free to spend their wealth in the way they please. This interpretation requires humans to remove themselves from the pit of selfishness, greed, and injustice. Therefore, Islamic social capital is important in describing how humans should utilise their wealth and optimize the benefits in a way that Allah (SWT) will bless. As stated in the Al-Quran, Surah Al-Hadiid (57:7): "Believe in Allah and His apostle, and spend (in charity) out of the (substance) where of He has made you heirs. For, those of you who believe and spend (in charity), for them is a great Reward". One of the fundamentals of Islamic social capital is zakat. Zakat as Islamic social capital plays an important role in the development of a Muslim country such as Malaysia. It is one of five fundamental obligations of Islam. Muslims contribute a portion of their income and wealth to a compulsory charitable mechanism. Zakat as social capital obligation brings blessings and impact not only to those who receive but also to those who contribute it.

Another primary source that associates the role of "Khalifah" with nature is through the Hadith by Prophet Muhammad (PBUH): "Every one of you is a leader and God al-Mighty will hold every one of you responsible for whatever is in your care." Previous literatures describe the three (3) stages of roles of a Khalifah; firstly, humans should protect the relationship between "Man and Allah (SWT)", secondly, the relationship between "Man and Man"; and thirdly, the relationship between "Man with other living creatures". In Surah alA'raaf (7:96), Allah (SWT) has revealed the importance of human beings in preserving other living creatures such as other life species (animals and plants), water, air, and land for the benefit of the entire world. It is crucial to avoid any harmful element that could cause a massive disruption on the ecological systems and the entire universe.

The question of how does social capital relates to the green economic growth in Malaysia. Though the green economic growth is associated with balance economic development that derives from a set of society as prescribed by Islamic Shariah, Malaysia as a Muslim country has been facing significant environmental issues. Hence, there is a need to find out if faith based social capital is a contributing factor to spur green economic growth in the short and long-run, especially in the case of Malaysia. The findings will help to understand how the redistribution of wealth and income support the green economic initiatives and how they complement each other.

\section{Data, Variables, and Methodology}


This paper utilises annual time series data and spans the time period of 1970 to 2015. The value for green economic growth (GE) is calculated using the real GDP (USD Dollar at a constant 2005) minus the costs of natural resources consumption and the costs of environmental depletion. In this perspective, Islamic social capital, through the yearly zakat (almsgiving) expenditures and household final consumptions, brings the values that could have a significant impact on this study. Annual zakat expenditures (Ringgit Malaysia) are aggregated for the 14 states in Malaysia and the Household final consumption is considered as US Dollar at a constant 2005. The capital input $(\mathrm{K})$ in the model is measured by Gross fixed capital formation (USD Dollar at constant 2005), which consists of expenditures on additions to the fixed assets of the economy plus the net changes in the level of inventories. The human capital is proxied by the total labor force, which includes people aged 15 and older who supply labor.

All data are obtained from the World Bank (2016) and Pusat Pungutan Zakat-Majlis Agama Islam Wilayah Persekutuan (PPZ-MAIWP, 2016). The green economic growth represents the calculation of economic growth and takes into the consideration the costs of natural resources consumption and environmental depletion as applied by Vaghefi et al. (2015) and Zheng and Chen, (2007). The study derives the green economic growth from the calculation of the real GDP (USD Dollar at constant 2005) discounted on pollution damages represented by $\mathrm{CO}_{2}$ emission (metric tons per capita) and natural resources damages, forest depletion (\% of Gross national income), mineral depletion (\% of Gross national income), and energy depletion (\% of Gross national income) as in the information provided by the World Bank (2015). This paper derives the following equation that was developed by Vaghefi et al. (2015) and Zheng and Chen (2007) on the association of social capital and green economic growth:

$$
Y_{t}=f\left(K_{t}, L_{t}, S_{t}\right)
$$

Where, $\mathrm{Y}$ is the real green economic growth; $\mathrm{K}$ is the capital stock; $\mathrm{L}$ is the human capital; $\mathrm{S}$ is the Islamic social capital and tenotes the specific time period.

The growth equation is obtained by taking the difference of Equation (1) and dividing by $Y_{t}$ with respect to its $i$ th. Thus, the growth equation is developed as follows:

$$
\begin{aligned}
& \partial \mathrm{Y}_{t}=Y K / \partial K_{t}+Y L / \partial L_{t}+Y S / \partial S_{t} \\
& \dot{\mathrm{Y}}_{\mathrm{t}}=\alpha \dot{\mathrm{K}}_{\mathrm{t}} \beta \dot{\mathrm{L}}_{\mathrm{t}} \delta \hat{\mathrm{W}}_{\mathrm{t}}
\end{aligned}
$$

where, Equation (3) shows the growth model for the green economic growth. The constant parameter that represents $\alpha, \beta$ and $\delta$ are the elasticity of output with respect to capital stock, human capital and Islamic social capital, accordingly.

This paper employs the Autoregressive Distributed Lag (ARDL) co-integration tests (Pesaran \& Shin, 1999; Pesaran et al., 2001), which performs better in determining cointegrating relationships in small samples (Romilly et al., 2001; Islam et al., 2013). The ARDL co-integration test applies irrespective of the regressors' order of integration, I $(0)$ or I(1). Thus, allowing for statistical inferences on long-run estimates are not possible under the alternative co-integration techniques. However, the linear ARDL co-integration technique is not valid in the presence of $\mathrm{I}(2)$ variables. In the context of co-integration, if the green economic growth and Islamic social capital are found co-integrated, it means that, although they may temporarily drift apart from each other, in the long run they tend to return to the equilibrium. The ARDL approach to cointegration (Pesaran et al., 2001) involves estimating the conditional error correction (EC) version of the ARDL model for the green economic 
growth and its determinants:

$\Delta y=\gamma_{1}+\gamma_{2} y_{t-1}+\gamma_{3} z_{t-1}+\gamma_{4} x_{t-1}+\sum_{i=1}^{p} \gamma_{i} \Delta y_{t-1}+\sum_{j=0}^{p} \alpha_{i} \Delta x_{t-j}+\sum_{s=0}^{p} w_{s} \Delta z_{t-s}+\mu_{i}$

where, $\gamma_{t}$ is a constant parameter and $\mu_{t}$ represents white noise processes. The ARDL bound testing approach to cointegration (Pesaran et al., 2001) allows establishing long-run relations among the variables. If the $F$ test statistics exceeds their respective upper critical values, we can conclude that there is evidence of a long-run relationship between the variables regardless of the order of integration of the variables. If the test statistics is below the upper critical value, we cannot reject the null hypothesis of no co-integration and if it lies between the bounds, a conclusive inference cannot be made without knowing the order of integration of the underlying regressors. The orders of the lags in the ARDL model are selected by the Akaike Information criterion (AIC) and the Schwarz Bayesian criterion (SIC). The ARDL specification of the short-run dynamics can be derived by constructing an error correction model (ECM). All coefficients with short-run equation are coefficients relating to the shortrun dynamics of the model's convergence to equilibrium and $\psi$ represents the speed of adjustment.

Goodness of fit of the ARDL model, diagnostic, and stability tests are conducted to assess the serial correlation and the heteroscedasticity associated with the model. The stability test is conducted using the cumulative sum of recursive residuals (CUSUM).

\section{Findings and Discussions}

\subsection{Analysis of Unit Root}

The Unit Root test indicates that two (2) variables; labor force (lnLF) and social capital (lnSC) are integrated at level I(0) with the statistical significance at the $1 \%$ and $5 \%$ level. Variables consist of green economic growth (lnGE), economic growth (lnG), capital fixed formation (lnGCF) and household final consumption (lnHHC) which are integrated in the first difference, $\mathrm{I}(1)$.

Table 1: Output of Unit Root Test

\begin{tabular}{ccccc} 
& \multicolumn{2}{c}{ Level } & \multicolumn{2}{c}{ First Difference } \\
VARIABLES & ADF & PP & ADF & PP \\
\hline $\ln$ GE & -1.5485 & -1.5088 & $-5.7401^{*}$ & $-5.7479^{*}$ \\
$\operatorname{lnG}$ & -1.5872 & -1.5475 & $-5.7412^{*}$ & $-5.7148^{*}$ \\
$\ln \mathrm{GCF}$ & -1.4731 & -1.4685 & $-5.9941^{*}$ & $-5.9851^{*}$ \\
$\ln \mathrm{HF}$ & $-3.5341^{*}$ & $-4.0563^{*}$ & $-4.4702^{*}$ & $-4.4036^{*}$ \\
$\ln \mathrm{HHC}$ & -0.3346 & -0.2571 & $-5.2067^{*}$ & $-4.2917^{*}$ \\
$\ln \mathrm{CC}$ & $-3.0674^{* *}$ & $-5.7847^{*}$ & $-6.1958^{*}$ & $-6.1958^{*}$ \\
\hline
\end{tabular}

Note: 1. Symbol *, **, *** indicates statistical significance at 1\%, 5\% and 10\% level; 2 . All variables are in natural logarithms.

\subsection{Analysis of Co-integration}

The calculated $F$-statistics for the co-integration test is presented in Table 2 . This study chose four (4) as the maximum order of lags in the ARDL based on the Akaike info criterion (AIC) and the Schwarz criterion (SIC) and the estimate for the period of 1970-2015, whilst ensuring that there is no evidence of serial correlation, as emphasized by Pesaran et al. (2001). The 
calculated $F$-statistics are higher than the upper bound critical value at $1 \%$ level of significance, using unrestricted intercept and no trend. Therefore, there is a co-integration relationship among the variables at the $1 \%$ level of significance.

Table 2: Statistical output for cointegration test (Bound test)

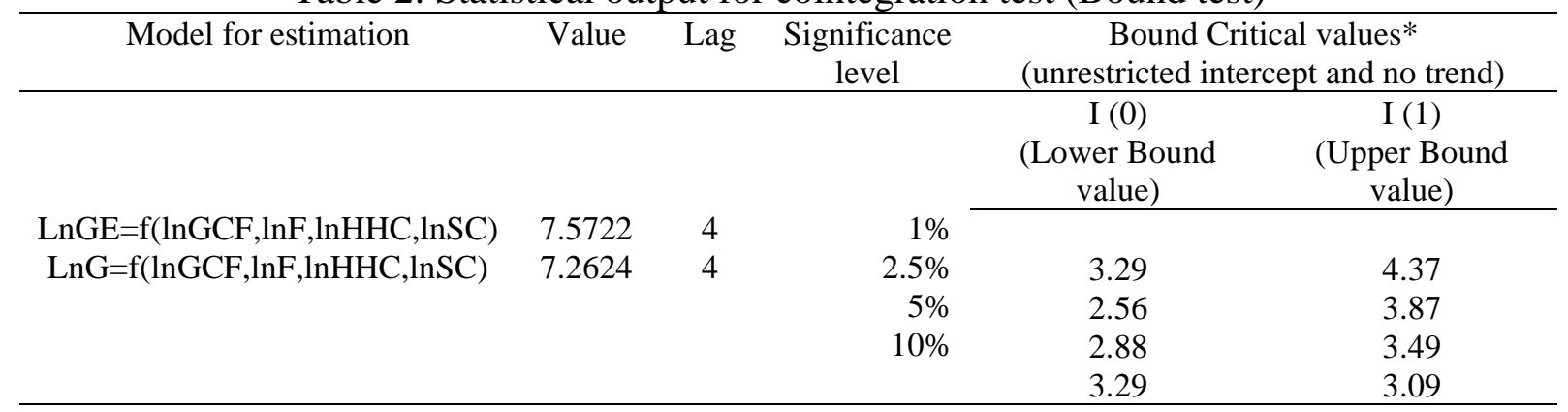

Note: Critical Values are cited from Pesaran et al. (2001)

\subsection{Assessment of the Long-Run Scenario}

The results for the long-run model are presented in Table 3. The significant variables which affect the green economic growth, are Gross capital formation (lnGCF) and Social capital (lnSC). All signs are consistent with the growth theories. The growth theories postulate that as capital increases, it contributes to a positive impact on the economic growth. It is consistent with the previous study done by $\mathrm{Wu} \& \mathrm{Wu}$ (2010). They found that the economic costs of natural resource depletion and pollution damages would in turn influence human welfare. Furthermore, a strand of study also found that Islamic social capital (zakat) has the capability to raise the economic growth in Malaysia. (Yusof, 2009; 2011; 2012; Patmawati \& Rahisam, 2010).

Moreover, this study reveals that Labor force (lnLF) and Household final consumption (lnHHC) are not significant in affecting the green economic growth in the long run. This result contradicts with the study done by Hezri and Ghazali, (2011), as human capital contributes to the green economic growth through a skilful and knowledgeable employment for the industry. The World Bank Report (2015) indicated that Malaysia's real GDP and the economic growth of the country in the past have been able to reduce poverty from 49.3 percent in 1970 to 1.0 percent in 2014. However, Hezri (2004 \& 2014) pointed out that even though the achievement is huge in terms of eliminating the previous poverty gap in a holistic perspective, the segregation of the wealth or income between the urban and rural area is still challenging. This could be in terms of the misallocation of capital into the economic sectors that causes poverty in the rural areas. Most of the main economic activities are conducted by the federal government in the urban areas, and the investors are convinced with all the facilities and infrastructure available in the area. In addition, UNEP (2012) indicated that the lack of economic activity in the rural areas indirectly limits the generation of income and accelerates the depletion of natural resources and ecosystems, which the poor rural communities depend on for their livelihood, nutrition, employment income, and wealth creation opportunity. The importance of natural resources for sustainable economic development and any reduction in natural capital stocks and ecosystems services flows may result in growing inequality.

Table 3: Long-run Model

\begin{tabular}{lcc}
\hline Independent variables/ Dependent variable & $(\ln G E)$ Coefficient & $($ lnG)Coefficient \\
\hline Constant & -7.5494 & -7.3634 \\
\hline
\end{tabular}




\begin{tabular}{lcc}
\hline $\ln G C F_{t}$ & $0.3050^{*}$ & $0.3044 *$ \\
& $(3.8587)$ & $(3.7033)$ \\
$\ln L F_{t}$ & 0.2748 & 0.2639 \\
& $(1.6764)$ & $(1.5610)$ \\
$\ln H H C_{t}$ & $0.1769 *$ & $(2.2598)$ \\
& $(2.3309)$ & $0.0031^{* * *}$ \\
$\ln S C_{t}$ & $0.0038^{* * *}$ & $(2.0236)$ \\
\hline R-squared & $(2.1563)$ & 0.9013 \\
F-statistics & 0.9173 & 3173.25 \\
Prob (F-stat) & 3437.85 & $(0.0000)$ \\
\hline
\end{tabular}

Note:

1. t-statistics are in parentheses;

2. *, **, *** Significant at 1\%,5\%, 10\% level, respectively.

\subsection{Assessment of the Short-Run Scenario}

The results of the error correction model are presented in Table 4. The positive sign of the coefficient of social capital supports the neoclassical economic growth model (Solow, 1956) which states that as the capital increases, it stimulates the economic growth in the short run. However, the labor force does not conform to the growth theory. A negative sign indicates that as the labor force increases, it deteriorates the economic growth in the short run. A similar result was found for the long run model; nevertheless, the findings imply a skilful and knowledgeable employment for the industry (Hezri \& Ghazali, 2011) and inequality of focus on development areas and income distribution (Hezri, 2004; 2014) contribute to a negative impact on the green economic growth. The significance of an error correction term (ECT) shows the evidence of causality in at least one direction. The lagged error term $\left(\mathrm{ECT}_{\mathrm{t}-1}\right)$ in our results is negative and significant at the $1 \%$ level. The value implies that the speed of adjustment for the short-run is at $0.5925 \%$, which indicates the rate of convergence towards the long-run equilibrium. The lag length for a short run model is selected using the AIC and SIC.

Table 4: Granger Causality Results based on VECM

\begin{tabular}{|c|c|c|c|c|c|c|c|}
\hline \multirow{2}{*}{$\begin{array}{l}\text { Dependent } \\
\text { Variable }\end{array}$} & \multicolumn{5}{|c|}{$X^{2}$-Statistics of lagged $1^{\text {st }}$ differenced term [p-value] } & \multicolumn{2}{|c|}{$E C T_{t-1}$ coefficient ( $p$-value) } \\
\hline & $\Delta \ln \mathrm{E}_{\mathrm{t}}$ & $\Delta / n G C F_{1}$ & $\Delta / n L F_{t}$ & $\Delta / n H H C_{t}$ & $\Delta \operatorname{lnSC_{t}}$ & $\Delta \operatorname{lnGE}$ & $\Delta \operatorname{lng}$ \\
\hline \multirow[t]{2}{*}{$\Delta / n G E_{\mathrm{t}}$} & - & $2.2034 * * *$ & 1.7250 & 0.0010 & $0.1932 * * *$ & $-0.2646^{*}$ & $-0.2602 *$ \\
\hline & & {$[0.0852]$} & [0.1962] & [0.9749] & [0.0799] & $(0.0000)$ & $(0.0000)$ \\
\hline \multirow[t]{2}{*}{$\Delta / n G C F_{t}$} & 0.9443 & - & 0.18066 & 2.0803 & 2.8349 & $0.1268 *$ & $0.1239 *$ \\
\hline & [0.3367] & & {$[0.9136]$} & {$[0.1566]$} & [0.0997] & $(0.000)$ & $(0.0000)$ \\
\hline \multirow[t]{2}{*}{$\Delta / n L F_{t}$} & 3.3954 & 3.2374 & - & 1.4829 & 1.8953 & 0.0001 & 0.0001 \\
\hline & [0.0724] & [0.0792] & & [0.1345] & [0.1857] & $(0.6463)$ & $(0.6682)$ \\
\hline \multirow[t]{2}{*}{$\Delta / n H H C_{t}$} & $0.3455^{*}$ & 2.0094 & 0.0145 & - & 0.047692 & $0.3716^{*}$ & $0.3825^{*}$ \\
\hline & [0.0098] & [0.1637] & [0.994] & & [0.9764] & $(0.0000)$ & $(0.0000)$ \\
\hline \multirow[t]{2}{*}{$\Delta \operatorname{lnSC_{t}}$} & 0.0964 & 0.0188 & 5.4682 & 0.1012 & - & -0.000075 & 0.000025 \\
\hline & [0.7577] & [0.8917] & [0.0242] & [1.8953] & & $(0.9446)$ & $(0.9812)$ \\
\hline
\end{tabular}

Note: ${ }^{*}, *$ and ${ }^{* * *}$ denotes significance at the $1 \%, 5 \%$ and $10 \%$ levels, respectively.

The results in Table 4 depict that there is a significant unidirectional causality from Gross fixed capital formation (lnGCF) and Social capital (lnSC) to green economic growth (lnGE). In addition, a unidirection exists from the green economic growth (lnGE) to Household final consumption (lnHHC). The findings reveal that the Gross fixed capital 
formation (lnGCF) and the Islamic social capital or Zakat (lnSC) are important elements that stimulate the green economic growth in the short run.

\subsection{Diagnostic Test}

The models have passed through several diagnostic tests. The values of $\mathrm{R}^{2}$ are estimated to be 91.7 and 91.3 percent in the long run, which indicates that the models are strong and a good fit (Table 3). Moreover, at the 5 percent significant level, the diagnostic tests confirm that there are no serial correlation and no heteroscedasticity problem in the models (Table 5).

Table 5: Statistical output for sensitivity test

\begin{tabular}{lllll}
\hline Model & Serialcorrelation & $\begin{array}{l}\text { Ramsey } \\
\text { Test }\end{array}$ & $\begin{array}{l}\text { Normality } \\
\text { test }\end{array}$ & $\begin{array}{l}\text { Heteroscedasticity Test } \\
\text { (Breusch-Pagan- } \\
\text { Godfrey) }\end{array}$ \\
\hline LnGE=f(lnGCF, lnF, $\ln H H C, \ln S C)$ & 0.4444 & 0.9213 & 0.9132 & 0.5392 \\
& $(0.6458)$ & $(0.3453)$ & $(0.6334)$ & $(0.8707)$ \\
LnG=f(lnGCF, $\ln , \ln H H C, \ln S C)$ & 0.4824 & 1.2075 & 0.7481 & 0.4977 \\
& $(0.6346)$ & $(0.2793)$ & $(0.6879)$ & $(0.8980)$ \\
\hline
\end{tabular}

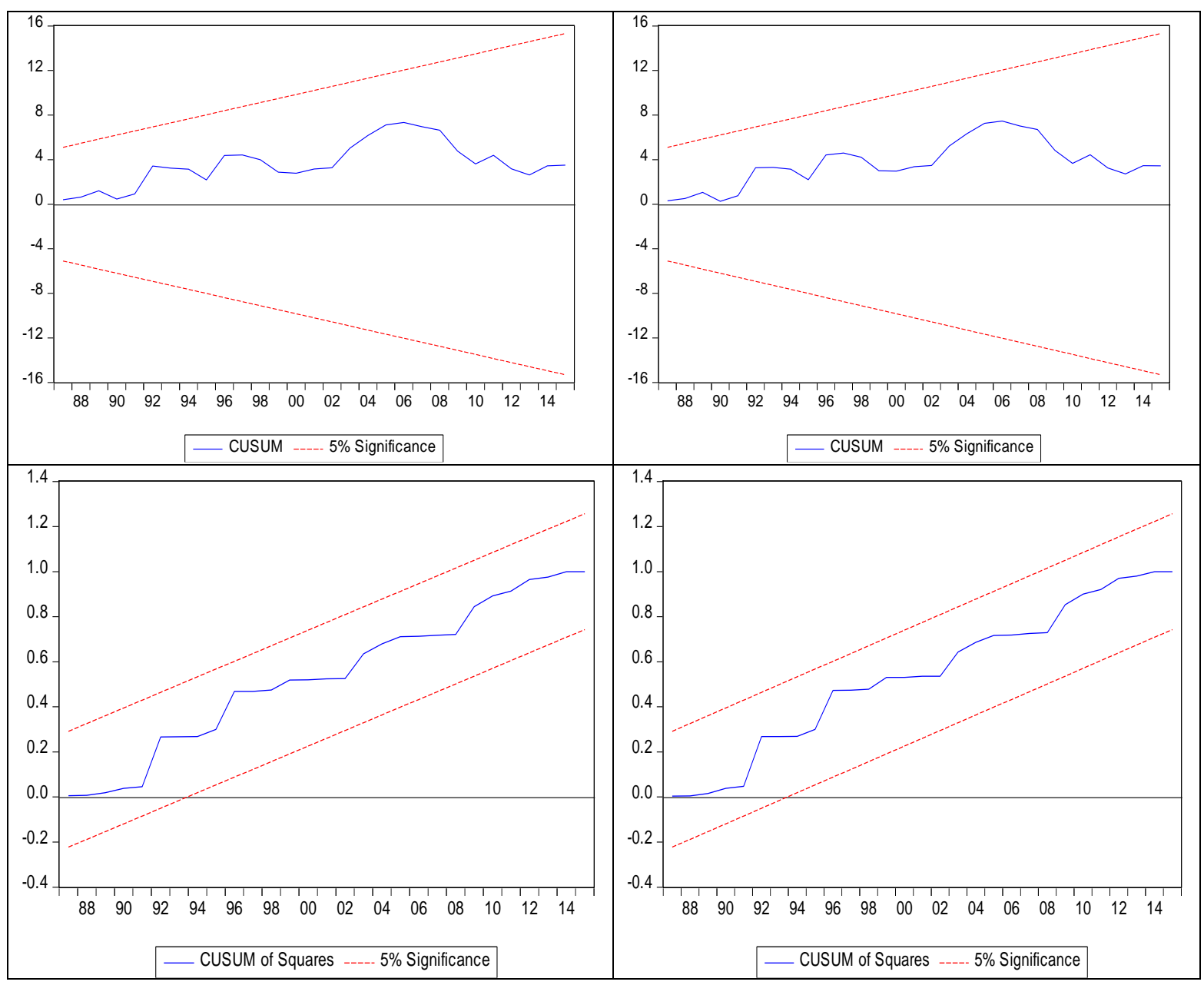

Figure 1: Plot of cumulative sum of recursive residuals, CUSUM test 
Furthermore, this study examines the stability of this model by using the structural stability CUSUM test (Figure 1). The results suggest that the values fall inside the critical bends at the $5 \%$ level. Therefore, the models are stable.

\section{Conclusions}

The paper examines the short-run and long-run relationships between social capital and the green economic growth in Malaysia. The green economic growth is an important instrument in achieving sustainable development and improving human well-being and social equity, while significantly reducing environmental risks and ecological scarcities (Hezri, 2004; 2011; Vaghefi et al., 2015). In Malaysia, the concept of a green economic growth is still at the developing stage with policy development (Hezri \& Ghazali, 2011; Vaghefi et al., 2015). As an emerging economy, Malaysia is experiencing environmental issues due to rapid economic growth that do not intensively balance the needs and demands of wealth accumulation. The present study employed the ARDL approach of cointegration to investigate the long-run relation between social capital and green economic growth, and the VECM Granger causality was used to test the direction of the causality. It utilizes the time series data from 1970 to 2014. The findings depict cointegration in the series and social capital contributes positively to the green economic growth in the long run. In addition, it also suggests that a short-run dynamic adjustment in a weak single directional causality impacts the green economic growth in Malaysia. The results imply that the value of social capital and green economic growth accounting are important to support human well-being in the economic activities.

The recent Climate Conference (COP21) and CMP11 of the Kyoto Protocol in Paris have established a "global consensus" in terms of realizing the impact of unlimited economic activity towards environmental delinquency. The imbalance of the ecological systems and the depletion of natural resources have been caused by economic development, which only benefits certain groups of rich people and countries around the world. The scarcity of resources, incremental global warming and pollutions; for instance, $\mathrm{CO}_{2}$ emissions from manufacturing and other economic development activity, the abuse of human capital, the poverty issue, and the unfair distribution of income still endure especially in the poor countries and developing countries such as Malaysia. Hence, an organized unanimity has to be driven by the well-developed countries that lavish capital and technological adequacies.

The justification underlies the Islamic teaching through the Maqasid al-Shariah inspiring the relevance of wealth protection. This is in tandem with the creation of humans by Allah as the vicegerents (Khalifah) of this universe. Therefore, an equitable economic growth measurement has to be established by developing a green economic growth accounting that is able to support the social well-being, environmental preservation, and fulfill the Maqasid alShariah. The efficient and blessed conduct would be based on the evidence that prescribed in the Al-Quran which provides the most efficient economic system.

\section{Acknowledgement}

This paper acknowledges the research funding contributed by the Ministry of Higher Education (MOHE) through the ARI HiCoE grant scheme.

\section{References}

Abdalati, H. (1980).Islam in Focus. Islamic Teaching Centre Riyadh. pp 126-129. 
Akram Ladin, M. (2013). Financing Green Technologies and the Role of Islamic finance: Sha'riah View. Green Economy Conference, KLCC Convention Center, Kuala Lumpur Malaysia. IBFIM.

Alam, M.M., Said, J., and Hassan, S. (2015). Performance of Islamic Microcredit in Terms of Maqasid Al-Shariah: Case Study on Amanah Ikhtiar Malaysia. Humanomics, 31(4): 374-384.

Al-Jayyousi, O. (2012). Islam and Sustainable Development: New Worldviews, Transformation and Innovation Series. Gower. England.

Al-Jayyousi, O. (2008). The State of Ecosystems and Progress of Societies. Proceedings of the Second OECD World Forum on Statistics, Knowledge and Policy: Measuring and fostering the progress of societies, Istanbul, 27-30 June 2007.

Auda, J. (2008). Maqasid al-Shariah as Philosophy of Islamic Law: A System Approach. The International Institute of Islamic Thought. London. Washington.

Chishti, S. (2003). Fitra: An Islamic Model for Humans and the Environment in Foltz,r,Denny, F., Baharuddin, A. (eds), Islamic and Ecology: A Bestowed Trust. Cambridge, MA: Harvard University Press, pp.67-82.

Costanza, R., Hart, M., Posner, S., and Talberth, J. (2009). Beyond GDP: The Need for New Measures of Progress. The Pardee Papers \# 4, pp.46.

RMK. (2015). Eleventh Malaysia Plan 2016-2020. The Economic Planning Unit, Prime Minister Department, Putrajaya.

EPU Malaysia (2009, 2011, 2013). Malaysia Quality of Life Index - MQLI. Government of Malaysia: Kuala Lumpur.

Green Technology Policy and Goal (2015).Ministry of Energy, Green Technology and Water (KeTTHa). Retrieved February 02, 2015 from http://www.kettha.gov.my

Hezri, A.A. (2004). Sustainability indicator system and policy processes in Malaysia: a framework for utilization and learning. Journal of Environmental Management 73 (2004): 357-371.

Hezri, A.A. (2014). Rearranging Government Agencies for the Sustainable Shift. Journal of Sustainability Science and Management.

Hezri, A.A. and Ghazali, R. (2011). A Fair Green Economy? Studies of Agriculture, Energy and Waste Initiatives in Malaysia. Occasional Paper Two: Social Dimensions of Green Economy and Sustainable Development. United Nations Research Institute. Retrieved April 15,2015 from http://www.fes-globalization.org/geneva.

Holling, C.S. (2000). Theories for Sustainable Futures: Conservation Ecology.4:7.

Retrieved April 15, 2015 from http://news.xinhuanet.com/environment/200609/07/content_5061909.htm.

Islam, F., Shahbaz, M., Ahmed, A.U., and Alam, M.M. (2013). Financial development and energy consumption nexus in Malaysia: A multivariate time series analysis. Economic Modelling, 30: 435-441.

Lane, J.E. (2015). $\mathrm{CO}_{2}$ emissions and GDP. International Journal of Social Economics, Vol.38, 11 pp. 911 -918.

LESTARI, (1999). Potential indicators for inclusion as sustainable development indicators (SDIs) for Malaysia. A report for the Economics Planning Unit on Strategic and Technical Support for the Development Indicators in Malaysia. Kuala Lumpur.

Lubchenco, J. (1998). Entering the Century of the Environment: A New Social Contract for Science, 279: 491-497.

Max-Neef, M. (1995) Economics growth and quality of life: a threshold hypothesis. Ecological Economics. 15:115-118. 
Nasr, S.H. (1992). Islam and the Environmental Crisis, in Rockefeller, Steven C. and Elder, John C. (eds), Spirit and Nature, Boston: Beacon Press, 83-108.

Nor, M.Y. (2011). Malaysia Quality of Life Index-MQLI: Government Printer, Kuala Lumpur.

OECD (2013). Investment framework in support of green growth: Investment Policy Reviews Malaysia 2013. Institute of Strategic and International Studies (ISIS) Malaysia.

Patmawati, H.I. and Rahisam, B.R.. (2010). The Impact of Zakat Distribution on Poverty Eradication and Distribution of Income Inequality in Negeri Sembilan. Prosiding Perkem, V: $104-113$.

Pesaran, H. and Y. Shin (1999). An Autoregressive Distributed Lag Modeling Approach to Co- integration Analysis, Cambridge, England.

Pesaran, H., Shin, Y., and R. Smith (2001). Bounds Testing Approaches to the Analysis of Level Relationships. Journal of Applied Econometrics, 16(3): 289-326.

PPZ-MAIWP. (2015). BukuLaporan Zakat Malaysia: StatistikKutipan Zakat Negeri di Malaysia. PusatPungutan Zakat, Majlis Agama Islam Wilayah Persekutuan. Kuala Lumpur.

Romilly, P.S. and Liu. X. (2001). Car Ownership and Use in Britain: A Comparison of the Empirical Results at Alternative Cointegration Estimation Methods and Forecast. Applied Economics 33, No.14: 1803-1818

Solow, R.M. (1956). A contribution to the Theory of Economic Growth. Quarterly Journal of Economics, 70(1): 65-94.

The World Bank Report (2015). Malaysia GDP overview. Retrieved October 09, 2015 from http://www.worldbank.org.

UNEP (2003). Green Economy: China's Pathway to a Green Economy. Retrieved April 18, 2015 from http://www.unep.org.

UNEP (2008). Green Accounting practice in China. Tongji Institute of Environment for Sustainable Development, College of Environmental Science and Engineering Tongji University. $\quad$ Retrieved $\quad$ May $18, \quad 2015$ from http://www.caep.org.cn/english/paper/Green-GDP-Accounting-Practice-in-China- byUNEP-Tongji-Team.pdf.

UNEP (2011). Towards a Green Economy: Pathways to Sustainable Development and Poverty Eradication, A Synthesis for Policy Makers. Retrieved Mac 20, 2015 from http://www.unep.org/greeneconomy.

UNEP (2012). Green economy, briefing paper: Poverty Reduction. Retrieved Mac 18, 2015 from http://www.unep.ch/etb/publications.

Vaghefi N., Siwar. C., and Aziz, S.A.A.G. (2015). Green GDP and Sustainable Development in Malaysia. Current World Environment, 10(1): 1-8.

World Bank (2015). Malaysia Economics Indicators. Retrieved April 18, 2015 from http://databank.worldbank.org/ddp/home.do.

$\mathrm{Wu}, \mathrm{J}$., and Wu, T. (2010). Green GDP. In: Berkshire Encyclopedia of Sustainability, Vol. IIThe Business of Sustainability. Berkshire Great Barrington, pp. 248-250.

Yusoff, M. (2009). An Analysis of Zakat Expenditure and Real Output: Theory and Empirical Evidence. The International Conference on Islamic Economics and Economies of the OIC Countries, 978-983.

Yusoff, M. (2011). Zakat Expenditure, School Enrollment, and Economic Growth in Malaysia. International Journal of Business and Social Science, 175-181.

Yusoff, M. and Densumite, S. (2012). Zakat Distribution and Growth in the Federal Territory of Malaysia. Journal of Economics and Behavioral Studies, 4(8): 449-456. 
Zheng, Y. and Chen, M. (2007). Promoting Green GDP for More Balanced Development. Environmental Policy and Law, 37(5): 416-421. 